\title{
RESEARCHES ON THE MEASUREMENT OF THE DISSOLVED OXYGEN CONCENTRATION IN STATIONARY WATERS
}

\author{
Gheorghe I. Gheorghe ${ }^{1}$, Octavian Donț ${ }^{2}$, Nicolae Băran ${ }^{3}$, \\ Corina Moga 4 , Mihaela Constantin ${ }^{5}$, Eugen Tămășanu ${ }^{6}$ \\ ${ }^{1}$ National Institute of Research and Development in Mechatronics and Measurement Technique, Bucharest \\ Sos. Pantelimon, no. 6-8, Sector 2, Bucharest \\ 2,4,5,6 Politehnica University of Bucharest \\ Splaiul Independenței no. 313, sector 6, Bucharest \\ ${ }^{3}$ DFR Systems SRL, Bucharest \\ Drumul Taberei no. 46, sector 6, Bucharest \\ E-mail: incdmtm@incdmtm.ro, octavdontu@yahoo.co, $\underline{n \text { baran fimm@yahoo.com, }}$ \\ corinamorega@yahoo.com, i.mihaelaconstantin@gmail.com,inregistrare@gmail.com
}

\begin{abstract}
The paper presents methods for measuring the dissolved oxygen concentration in water; the electrical method is presented by presenting an experimental installation designed and built in the laboratories of POLITEHNICA University in Bucharest. For the creation of fine air bubbles, a bubble generator with $0.1 \mathrm{~mm}$ orifices processed by spark-erosion was used. The results of the experimental researches on the measurement of dissolved oxygen in water are presented.
\end{abstract}

Keywords: Water aeration, fine bubble generators, spark-erosion.

\section{Introduction}

The main purpose of water aeration, irrespective of the industry and the reason it is used, is to increase or maintain an optimal level of dissolved oxygen in water mass.

The oxygen required for the aeration process is taken from the atmospheric air and introduced into the water. In order for this aeration to be effective, uniform air dispersal must be ensured throughout the mass of water in a tank or basin; the air must be spread evenly so as to ensure the oxygen demand. Dissolved oxygen content is the most important indicator of water quality.

Fishes, for example, need to survive a dissolved oxygen concentration up to $5 \mathrm{mg} / \mathrm{dm}^{3}$ [1]. The amount of oxygen in the water is consumed by different biological or chemical processes. The amount of water remaining in these processes depends on the rate of deoxygenating and oxygenation rate (aeration), which can occur naturally or artificially [2, 3].

By aerating the water means transferring oxygen from atmospheric air into water, which is actually a phenomenon of transferring a gas into a liquid.

The most common method of removing impurities of organic nature under the action of a biomass of aerobic bacteria is the introduction of gaseous oxygen into the waste water. Oxygen originates most frequently from atmospheric air, in this case the process known as water aeration (Figure 1).
The dissolved oxygen in water is measured in $\mathrm{mg}$ $\mathrm{O}_{2} / \mathrm{dm}^{3}$.

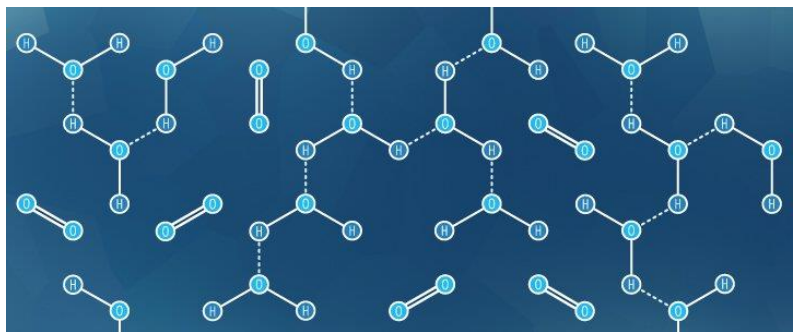

Figure 1: Free oxygen molecules in water [4]

From the above figure one can observe that each water molecule consists of an oxygen molecule connected to two hydrogen molecules. The oxygen molecules constituting the dissolved oxygen can be found among water molecules The maximum amount of oxygen that can be dissolved in water depends on a number of physical and chemical parameters such as: atmospheric pressure, water temperature, salinity, turbulence of water $[5,6]$. Water temperature is an important factor, so the warmer the water, the lower the dissolved oxygen concentration. So [1]:

- at $\mathrm{t}=10^{\circ} \mathrm{C}$, in fresh, clean water, an amount of $11,3 \mathrm{mgO}_{2} / \mathrm{dm}^{3}$ can be absorbed;

- at $\mathrm{t}=25^{\circ} \mathrm{C}$, in clean water, only $8.3 \mathrm{mgO}_{2} /$ $\mathrm{dm}^{3}$ can be absorbed.

Oxygenation processes are found in the following areas $[7,8]$ :

- in sewage treatment and treatment plants; 
- in disinfection (by ozonation) stations of raw water taken from a source in order to make it drinkable;

- in the chemical industry;

- in the food industry, fish industry, etc.;

-in water treatment and purification processes, oxygenation (sometimes referred to as aeration) is a basic process in ensuring water quality.

\section{Presentation of Methods that are Used to Measure the Dissolved Oxygen Concentration in Water}

The analytical techniques used to determine the dissolved oxygen concentration in water are based on the following methods $[9,10,11]$ :

\subsection{Chemical methods}

The technique uses the IODOMETRIC method for determining the (DO) content in drinking water based on the Winkler process [12]. This method is increasingly less used because electrical and optical methods have emerged.

The main disadvantages of chemical methods are: -the presence of catalysts used for deoxygenating;

- the presence of oxygen in reagents;

- the occurrence of errors in the titration process;

- cannot monitor DO instantly or continuously;

- it consumes more time than electrical or optical methods.

\subsection{Electrical methods}

The electrical methods named in some works electrochemical methods are based on two techniques for measuring the dissolved oxygen concentration in water:

a) galvanic technique where there is very little electrical voltage between electrodes, no external voltage is required [9];

b) the technique of the polarographic process, in which an electric voltage (direct current) is applied between the two electrodes (cathode and anode).

In the following, only the polarographic process is analyzed.

The devices used to measure DO in water are called oxygen meters.

Overall, an oxygen meter is composed (Figure 2) of a microprocessor (1) connected to a probe (3) which is introduced into water whose OD content has to be measured.

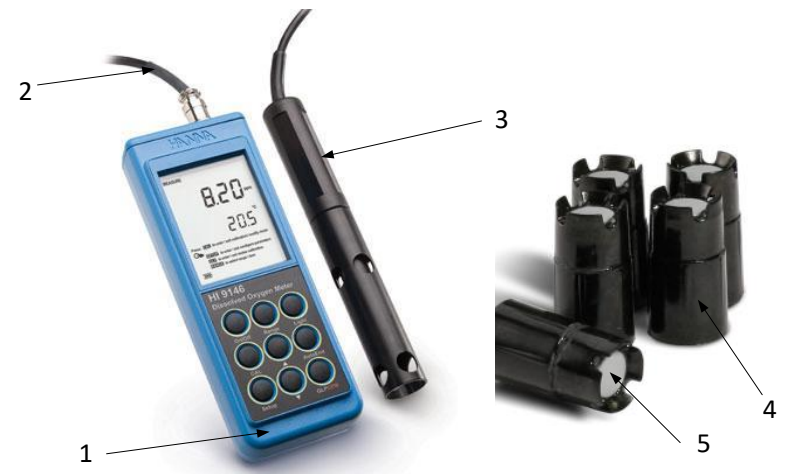

Figure 2: Oxygen meter used for measurements 1 - microprocessor; 2 - connecting cable; 3 - probe body; 4 - small cylinder containing an electrolyte solution; 5 - oxygen permeable Teflon membrane

The oxygen flowing through the permeable oxygen Teflon membrane (5) causes a change in the electric current between the cathode and the anode in a small cylinder containing an electrolyte solution (4); this change is proportional to the amount of oxygen that penetrated through the membrane and is displayed on the microprocessor screen in [mg / $\left.\mathrm{dm}^{3}\right]$.

Disadvantages of Electrical Methods:

1. difficulty in calibrating and maintaining the device (electrode cleaning and membranes replacement); device;

2. electrolyte consumption during use of the

3 . the devices are relatively expensive between $600 \div 1500 €$;

4. the disappearance of oxygen molecules in the vicinity of the sensor can only be prevented by keeping the sample of water or the probe in motion.

Points 1 and 2 can only be solved by regular calibrations and electrolyte changes.

Advantages of electric methods:

1. the apparatus is portable; measurements can be made in the laboratory, swimming pools, lakes, ponds;

2. the device monitors the DO concentration instantly or continuously;

3. no sampling equipment is required.

In the laboratory of the Department of Thermotechnics, Engines, Thermal and Refrigeration Equipment's there is such an oxygen meter that is used in experimental researches on water oxygenation.

\subsection{Optical methods}

Optical methods include reflection spectroscopy, light analysis transmitted by translucent electrodes and ellipsometry. 
In 2003, HACH LANGE became the first manufacturer of measuring instruments to launch the L.D.O. (Luminescent Dissolved Oxygen Luminescent dissolved oxygen) to determine dissolved oxygen in water.

The device consists of a microprocessor (1), a connecting cable (2) and a probe inserted into the water (3) (Figure 3).

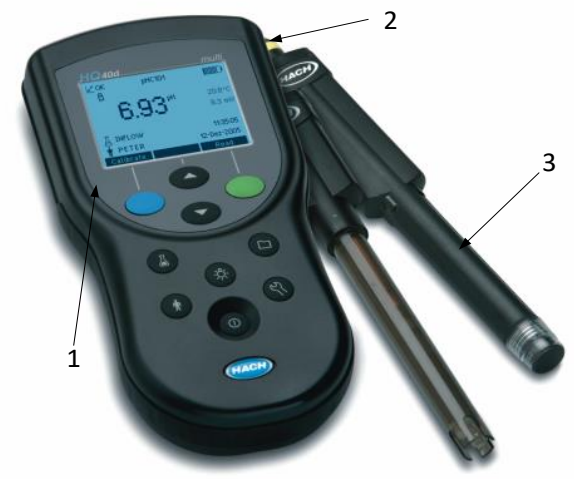

Figure 3: DO meter based on L.D.O.

1 - microprocessor; 2 - connecting cable;

3 - probe that is inserted into the water

Technical data on the meter based on L.D.O. are presented in the table below:

\begin{tabular}{|c|c|}
\hline $\begin{array}{c}\text { Method of } \\
\text { measurement }\end{array}$ & Luminescence, optical \\
\hline Excitation & Pulses of blue light \\
\hline Calibration & Not required \\
\hline $\begin{array}{c}\text { Measuring } \\
\text { range }\end{array}$ & $\begin{array}{c}0.1 \text { to } 20 \mathrm{mg} / \mathrm{dm}^{3}(\mathrm{ppm}) \mathrm{O} 2 ; \\
1-200 \% \mathrm{O}_{2} \text { saturation; } 0.1- \\
50^{\circ} \mathrm{C}\end{array}$ \\
\hline Accuracy & $\begin{array}{c} \pm 0,1 \mathrm{mg} / \mathrm{dm}^{3} \mathrm{O}_{2}<1 \mathrm{mg} / \\
\mathrm{dm}^{3} ; \pm 0,2 \mathrm{mg} / \mathrm{dm}^{3} \mathrm{O}_{2}>1 \mathrm{mg} \\
/ \mathrm{dm}^{3}\end{array}$ \\
\hline $\begin{array}{c}\text { Reproducibility } \\
\pm 0,5 \% \text { of the final value of the } \\
\text { measurement range }\end{array}$ \\
\hline $\begin{array}{c}\text { Response Time } \\
\mathrm{T} 90<40 \mathrm{sec}\left(20^{\circ} \mathrm{C}\right), \mathrm{T} 95<60 \\
\mathrm{sec}\left(20^{\circ} \mathrm{C}\right)\end{array}$ \\
\hline $\begin{array}{c}\text { Temperature } \\
\text { range }\end{array}$ & $00^{\circ} \mathrm{C}$ \\
\hline
\end{tabular}

The operating principle of L.D.O. is based on the physical phenomenon of luminescence; it is defined as the property of materials to emit light when excited.

For a suitable combination between luminophore and an excitation light of a given wave, the luminosity intensity and the time to disappear is dependent on the oxygen concentration around the luminophore.

The probe Hach Lange - L.D.O. is composed of two elements (figure 3):

a) the head of the probe, on which there is a luminophore layer deposited on a transparent transfer material; the measurements of the head are screwed into the body of the probe that floats in water (Figure 4);

b) the probe body, comprising a blue LED that emits the light needed to create luminescence, a red LED as a reference item and a photodiode.

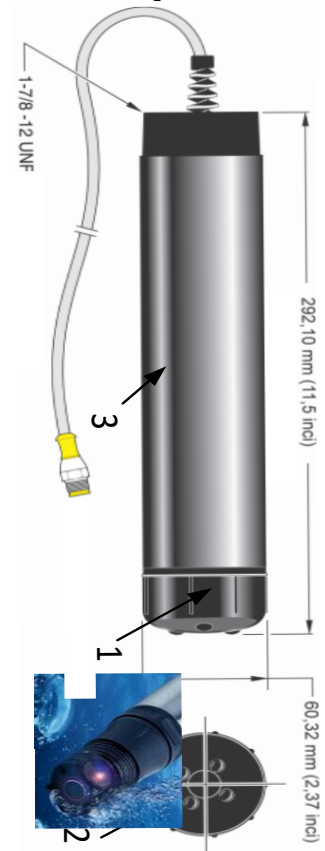

Figure 4: HACH LANGE probe - L.D.O.

1 - probe head; 2-layer luminophore; 3 - probe body

In operation, the blue light emits pulses of blue light (excitation light) that reaches the luminophore, to which it transfers some of its radiant energy. As a result, some of the electrons in the luminophore layer leap from their original level to a higher energy level.

After a very short time, they return to their original level, emitting energy that they lose as red light (Figure 5).

Oxygen molecules are able to absorb the energy of high-level electrons and allow them to return to their normal level without emitting red light.

The higher the oxygen concentration, the greater is the reduction in the intensity of the red light emitted.

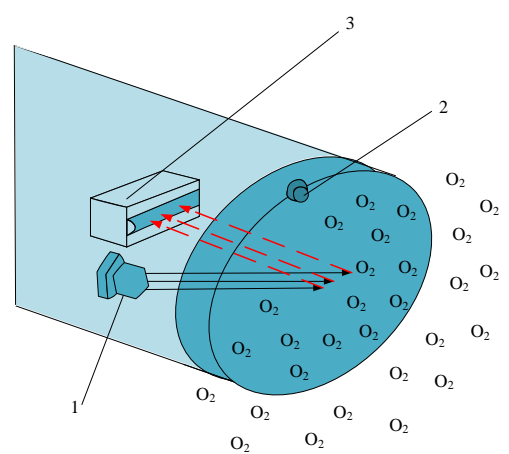

Figure 5: Operating principle for HACH LANGE L.D.O. 1 - Blue LED; 2 - Red LED; 3 - photodiode 
As electrons return to low energy levels faster, the lifetime of the red light emitted is shortened. To determine the oxygen concentration, the lifetime of the red light is evaluated. So, the DO measurement is based on the physical measurement of time.

Advantages of the L.D.O.:

1) optical method L.D.O. measures the concentration of dissolved oxygen in water based on the measurement of an exact time.

2) the method requires only that the oxygen molecules be in contact with the luminophor.

3) any cleaning of the luminophore in the probe head does not affect the lifetime of red light emitted, which depends only on the oxygen concentration in the sample.

4) all optical components of the probe are adjusted before each measurement using the red reference LED.

Before each measurement, it transmits a beam of light that reflects in the luminophore and passes through the entire optical system in the same way as light from luminescence.

Disadvantages of the L.D.O.:

1) cleaning the probe head;

2) changing the probe head once every 2 years.

\subsection{Non-invasive method}

The current variety of applications, industrial or laboratory, requiring real-time monitoring of fluids variation in oxygen, has led to the development of several measurement methods.

Non-invasive measurement of dissolved oxygen concentration is the most recent method used in the food and beverage industry.

The determinations are accurate and can be done by means of a sensor applied to a transparent surface (glass or transparent plastic) (figure 6).

The principle of the measuring devices is that of oxo-luminescence $[13,14]$.

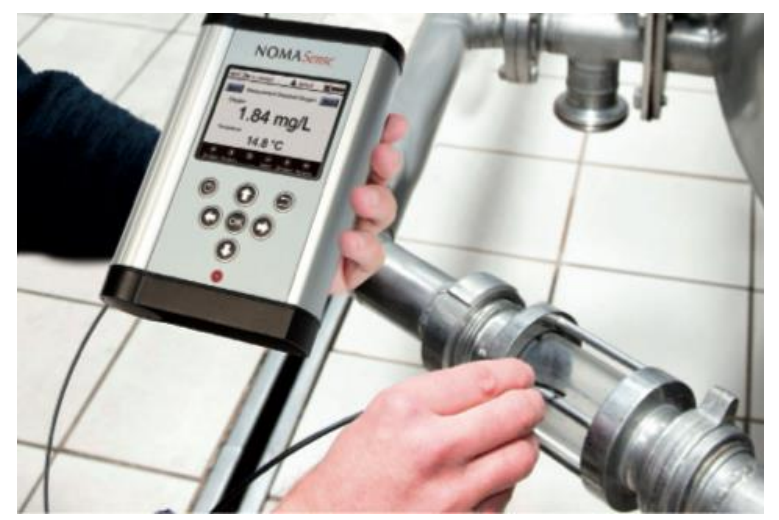

Figure 6: Non-invasive device for measuring dissolved oxygen concentration

Fig. 6 shows how to use a non-invasive device for measuring the concentration of dissolved oxygen in water passing through a pipe [14].
The main features of this device are: it uses a non-invasive, non-destructive method; applicability in gaseous or liquid media; long life of sensors without complicated calibration or maintenance operations; usable in industrial or laboratory environments; easy to use, portable and versatile; accurately determine the dissolved oxygen content in water.

\section{Experimental Researches on the Determination of Dissolved Oxygen in Water by the Electrical Method}

The fine bubble generator (FBG) is fed by its two ends, namely through the 16 and 17 pipes (Figure 7).

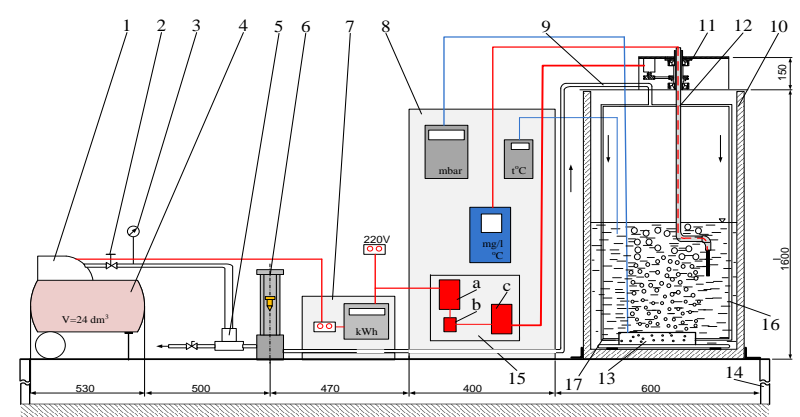

Figure 7: The scheme of experimental installation for research on water oxygenation

1-compressed air compressor; 2- pressure reducer;

3-manometer; 4-compressed air tank $V=24 \mathrm{dm}^{3}$;

5- T-joint; 6-rotameter; 7- electric panel; 8-panel with measuring devices; 9-compressed air pipeline to FBG .;

10- water tank; 11 - probe actuation mechanism;

12- Oxygen probe; 13-FBG of rectangular shape;

14 - support for the installation; 15-electronics

control: $a$ - power supply, $b$ - switch, $c$ - control element; 16, 17 - FBG with compressed air

Regarding the experimental installation it is stated $[15,16]$ :

- the gas flow and pressure can be measured to ensure water oxygenation:

*atmospheric air,

* atmospheric air with low-nitrogen content.

- hydrostatic load can be changed in range 0.5 ; $1.0 ; 1.5 \mathrm{~m}$.

- it can be precisely measured with digital indicating devices: pressure, temperature and flow of the gas introduced into the water tank.

- one can measure the instantaneous change of dissolved oxygen concentration in water or at time $\Delta \mathrm{t}$ with the oxygen meter whose probe is actuated by an electric mechanism.

For the operation of the experimental installation, electric current is needed to drive the electro compressor, the mechanism of rotating the oxygen sensor probe into the water tank. 
The system works as follows: the air compressed by an electro compressor 1 (Figure 7) accumulates at $\mathrm{p}=1.5-2$ bar in a $24 \mathrm{dm}^{3}$ tank. Subsequently, the air passes through the reducer (2) through the manometer (3) and reaches the FBG (13).

During an experiment, the volumetric air flow rate, the pressure at the entrance to the FBG ( $\mathrm{p}_{\mathrm{FBG}}$ and hydrostatic load $(\mathrm{H})$ are maintained constant.

The panel (15) with the control electronics provides, via the mechanism (11), the rotation of the oxygen sensor probe in the water tank at a speed of $0.3 \mathrm{~m} / \mathrm{s}$.

For measuring the pressure and temperature of the air and the dissolved oxygen concentration in the water, digital indicating devices are provided on the panel (8) of Figure 7, namely:

a) for the flow rate measurement a rotameter with a scale of $0 \div 2200 \mathrm{dm}^{3} / \mathrm{h}$ for air was provided.

b) a manometer with a digital indication in the range $0 \div 190$ mbar was provided for the pressure measurement.

c) the measurement of temperature was performed with a digital thermometer with a scale of $50 \div 150 \stackrel{\circ}{ } \mathrm{C}$.

d) the dissolved oxygen concentration in water was measured on the basis of the electric method $[17,18]$ using a polarographic probe oxygen sensor.

To carry out the measurements, the oxygen sensor was rotated in the water tank with 2 rot / s; for its rotation an electro-mechanical mechanism realized in the Department of Thermotechnics, Engines, Heat and Refrigeration Equipment's was designed.

The measurement of the dissolved oxygen concentration in water is based on the electrical method. The oxygen meter has a polarographic probe to be displaced during the measurements; the displacement consists of a rotation movement of 0.3 $\mathrm{m} / \mathrm{s}$ (value required in the Oxygen Leaflet). The probe radius is $0.125 \mathrm{~m}$.

The speed that the mechanism ensures is thus established $[19,20]$ :

$$
w=\omega \cdot r[m / s]
$$

$$
\begin{aligned}
& \omega=\frac{w}{r}=\frac{0.3}{0.125}=2.4\left[\frac{\mathrm{rad}}{\mathrm{s}}\right] \\
& \omega=\frac{2 \pi \cdot n}{60} \\
& n=\frac{60 \cdot \omega}{2 \pi}=\frac{60 \cdot 2.4}{2 \pi}=22.92 \mathrm{rot} / \mathrm{min}
\end{aligned}
$$

The purpose of the researches is to experimentally determine the variation in dissolved oxygen concentration in water.

Figure 8 shows the FBG with 152 orifices $\varnothing$ $0.1 \mathrm{~mm}$ in operation $[20,21,22]$.

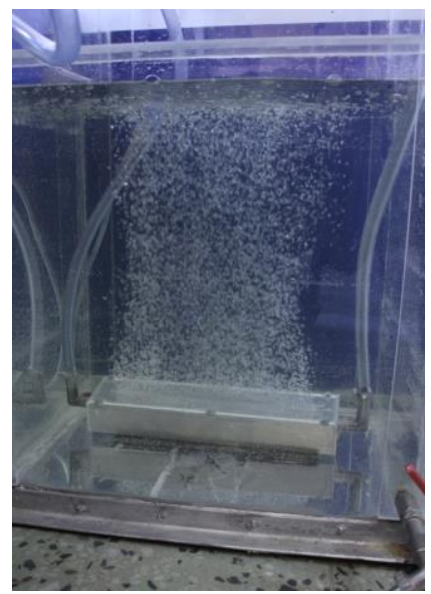

Figure 8: FBG with 152 orifices $\varnothing 0.1 \mathrm{~mm}$ in operation

For experimental researches, as initial data it is specified:

- the airflow introduced in the FBG: $600 \mathrm{dm}^{3} / \mathrm{h}$

- the air pressure at the FBG entrace.$: \mathrm{p}=573$ $\mathrm{mmH}_{2} \mathrm{O}$

- water temperature: $\mathrm{t}=24 \stackrel{\mathrm{o}}{\mathrm{C}}$

- the initial concentration value: $\mathrm{C}_{0}=5.48 \mathrm{mg} /$ $\mathrm{dm}^{3}$

- Corresponding to the water temperature, the value of the saturation concentration: $\mathrm{Cs}=8.4 \mathrm{mg} /$ $\mathrm{dm}^{3}$

The experimental researches resulted are presented in Table 1. OD-Oxygen Dissolved in Water.

Table 1. Experimental data obtained from the FBG of rectangular shape with 152 orifices

\begin{tabular}{|c|c|c|c|c|c|c|c|c|c|}
\hline No & 0 & 1 & 2 & 3 & 4 & 5 & 6 & 7 & 8 \\
\hline$\tau[\mathrm{min}]$ & 0 & 15 & 30 & 45 & 60 & 75 & 90 & 105 & 120 \\
\hline $\mathrm{t}_{\mathrm{H} 2 \mathrm{O}}\left[{ }^{\circ} \mathrm{C}\right]$ & \multicolumn{10}{|c|}{23,7} \\
\hline $\mathrm{t}_{\text {aer }\left[{ }^{\circ} \mathrm{C}\right]}$ & \multicolumn{10}{|c|}{24,1} \\
\hline $\begin{array}{c}\mathrm{OD}[\mathrm{mg} / \\
\left.\mathrm{dm}^{3}\right]\end{array}$ & 5.4 & 7.3 & 7.85 & 8.0 & 8,2 & 8.3 & 8.31 & 8.37 & 8.39 \\
\hline
\end{tabular}

Based on the data in Table 1, the function $C=f(\tau)$ of Figure 9 was plotted. 


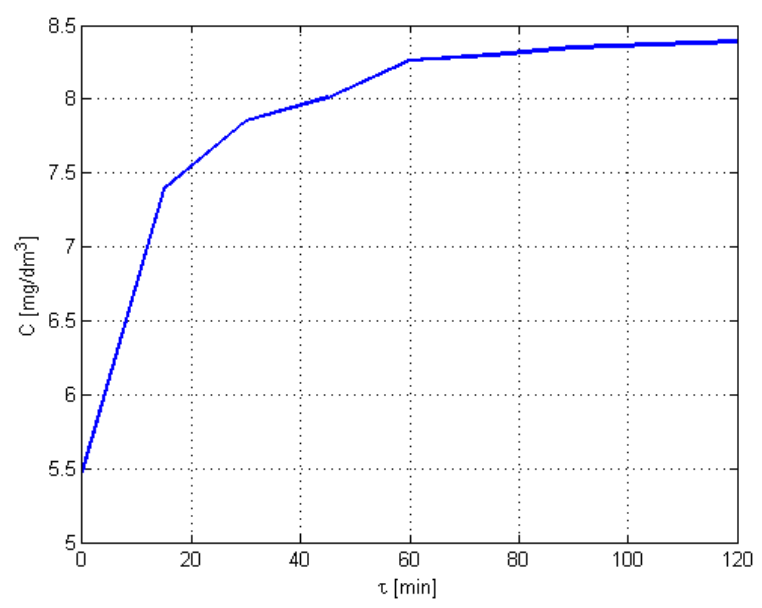

Figure 9: The variation of the dissolved oxygen concentration in water, in time $C=f(\tau)$

The presented experimental results coincide very well with the theoretical results of the function $\mathrm{C}=\mathrm{f}$ $(\tau)$ presented in the papers $[23,24,25,26]$.

\section{Conclusions}

The measurement of the dissolved oxygen concentration in water is necessary because it ensures the existence of water life forms within certain limits.

Out the methods of measuring the dissolved oxygen concentration in water, the most commonly used is the electrical method; it has the advantage of instantly indicating the change in oxygen concentration on a computer screen. It has the disadvantage that during the measurement, the probe must be driven in rotation by an electromechanical mechanism.

The non-invasive method presented in paragraph 2.4 is a modern method that makes it easy and accurate to perform measurements.

\section{Acknowledgements}

This work was supported by a grant of the Romanian National Authority for Scientific Research and Innovation, CCCDI - UEFISCDI, project number Manunet - MNET17/ENER2307 - CEBIOTREAT, within PNCDI III.

\section{References}

[1] G. Oprina, I. Pincovschi, Ghe. Băran, Hidro-GazoDinamica Sistemelor de aerare echipate cu generatoare de bule, Ed. POLITEHNICA PRES, Bucureşti 2009.

[2] D. Robescu, D.L. Robescu, Procedee, instalaţii şi echipamente pentru epurarea apelor, Litografia UPB, Bucureşti, 1996.
[3] L. R. Droste, Theory and Practice of Water and Wastewater Treatment, 1996. ISBN 978-0-47112444-3 - John Wiley \& Sons Inc.

[4] I. Călușaru, Influenţa proprietăţilor fizice ale lichidului asupra eficienţei proceselor de oxigenare, Teză de doctorat, Universitatea Politehnica din București, Facultatea de Inginerie Mecanică și Mecatronică, 2014.

[5] Al. S. Pătulea, Influenţa parametrilor funcţionali şi a arhitecturii generatoarelor de bule fine asupra eficienței instalaţiilor de aerare, Teză de doctorat, Universitatea Politehnica din Bucureşti, 2012.

[6] G.Oprina, Contribuţii la hidro-gazo-dinamica difuzoarelor poroase, Teză de doctorat, Universitatea Politehnica din Bucureşti, Facultatea de Energetică, 2007.

[7] D. Robescu, D. L. Robescu, A. Verestoy, Fiabilitatea proceselor, instalaţiilor şi echipamentelor de tratare şi epurare a apelor, Ed. Tehnică, Bucureşti, 2002.

[8] D. L. Robescu, S. Lanyi, A. Verestoy, D. Robescu, Modelarea şi simularea proceselor de epurare, Ed. Tehnică București, 2004.

[9] N. Băran, A. Patulea, I. Căluşaru, The Determination of The Oxygen Transfer Spead In Water In Nonstationary Conditions, International proceedings of Computer Science and Information Technology, Mechanichal Engineering, Robotics and Aerospace, 2011, pp 267-272.

[10] Al. Pătulea, N. Băran, I. M. Căluşaru, Measurements of Dissolved Oxygen Concentration in Stationary Water, World Environment, vol. 2(4), 2012, pp. 106-109.

[11] I. M. Căluşaru, A. Costache, N. Băran, G. L. Ionescu, O. Donţu, The determination of dissolved oxygen concentration in stationary water, Applied Mechanics and Materials, Trans Tech Publications, Switzerland, vols. 436, 2012, pp. 233-237.

[12] I. Pincovschi, Hidrodinamica sistemelor disperse gaz-lichid, Teză de doctorat, Universitatea Politehnica din Bucureşti, 1999.

[13] Dr. Thomas, O. Mitchel, Luminescence based Measurement of Dissolved Oxygen in Natural Waters, www.hachenvironmental.com, 2006.

[14] Noninvasive D.0, Measurement http://www.nomacerc.com/enology/nomasense _02_p300.

[15] I. Căluşaru, N. Băran and A. Pătulea, The influence of the constructive solution of fine bubble generators on the concentration of oxygen dissolved in water, Advanced Materials Research, Trans Tech Publications, Switzerland, Vols. 538541, 2012, pp. 2304-2310,.

[16] Al. Pătulea, I. M. Căluşaru, N. Băran, Reasearches regarding the measurements of the dissolved concentration in water, Advanced Materials Research, Trans Tech Publications, Switzerland, vols. 550-553, 2012, pp. 3388-3394. 
[17] M. Călușaru-Constantin, E. B. Tănase, N. Băran and Rasha Mlisan-Cusma, Researches Regarding the Modification of Dissolved Oxygen Concentration in Water, IJISET - International Journal of Innovative Science, Engineering \& Technology, Vol. 1 Issue 6, 2014, pp. 228-231.

[18] M. Constantin, N. Băran, B Tănase, A New Solution for Water Oxygenation, International Journal of Innovative Research in Advanced Engineering (IJIRAE), Vol. 2,Issue 7,2015, pp.49-52.

[19] Al. Dobrovicescu, N.Băran, Al.Chisacof, Bazele termodinamici Tehnice, Elemente de Termodinamică Tehnică, Ed. POLITEHNICA PRESS, 2009.

[20] Gh. Băran, I. Pincovschi, G.Oprina, F. Bunea, Performanțe ale generatoarelor de bule fine, Revista Hidrotehnica, București, vol.53, nr. 3-4, pp. $27 \div 32,2008$.

[21] B. Tănase , D. Besnea , R. Mlisan , M. Constantin and N. Băran, Constructive solutions for the achievement of fine bubble generators based on micro-drilling technologies, IJISET International Journal of Innovative Science, Engineering \& Technology, Vol. 2 Issue 2, 2015, pp. 46-50.

[22] E. B. Tănase, N. Băran, R. Mlisan, An Efficient Solution for Water Oxygenation, Asian Engineering Review Vol. 1, No. 3, 36-40, 2014.
[23] Nicolae Băran, Alexandru Sorin Patulea, Ionela Mihaela Căluşaru, The Determination Of The Oxygen Transfer Spead In Water In Nonstationary Conditions, International proceedings of Computer Science and Information Technology, Mechanichal Engineering, Robotics and Aerospace, IACSIT PRESS, ISSN: 2010-460X, ISBN 978-981-07-04209, pag 267-272, 2011.

[24] I. M. Căluşaru, N. Băran, Al. Pătulea, The influence of the constructive solution of fine bubble generators on the concentration of oxygen dissolved in water, Advanced Materials Research, Trans Tech Publications, Switzerland, vols. 538541, 2012, pp .2304-2310.

[25] M. Constantin, N. Băran, B. Tănase, A New Solution for Water Oxygenation, International Journal of Innovative Research in Advanced Engineering (IJIRAE), Vol. 2, Issue 7, 2015, pp. 4952.

[26] I. M. Căluşaru, N. Băran, Al. Pătulea, Researches regarding the transfer of oxygen in water, The 3rd International Conference on Mechanic Automation and Control Engineering (MACE 2012) July 27th -29th, published by IEEE Computer Society CPS, and then submitted to be indexed by Ei Compendex, Baotou, China, 2012, pp. 2617-2620. 